\title{
THE NOVEMBER MEETING IN COLUMBIA
}

The five hundred forty-first meeting of the American Mathematical Society was held at the University of Missouri, Columbia, Missouri, on Friday and Saturday, November 29 and 30, 1957. There were about 75 registered including 60 members of the Society.

The Committee to Select Hour Speakers for Western Sectional Meetings had invited Professor Daniel Zelinsky of Northwestern University to address the Society. He spoke on the topic Homological algebra in Room 100, Stewart Hall, at 2:00 P.M. Friday. The presiding officer was Professor J. L. Zemmer.

There were two sessions for the presentation of contributed papers, one at 3:15 P.M. on Friday with Professor L. M. Kelly presiding, and the other at 10:00 A.M. Saturday with Professor W. G. Leavitt in charge.

Members of the Society and their friends were entertained at a tea held in the Student Union immediately following the sessions on Friday afternoon. An informal dinner was held in one of the restaurants on Friday night.

Abstracts of the contributed papers will be published in the February and April issues of the Notices of the American Mathematical Society.

J. W. T. Youngs, Associate Secretary 